ELORE (ISSN 1456-3010), vol. $18-1 / 2011$.

Julkaisija: Suomen Kansantietouden Tutkijain Seura ry. [http://www.elore.fi/arkisto/1_11/kirjat_hakkinen.pdf]

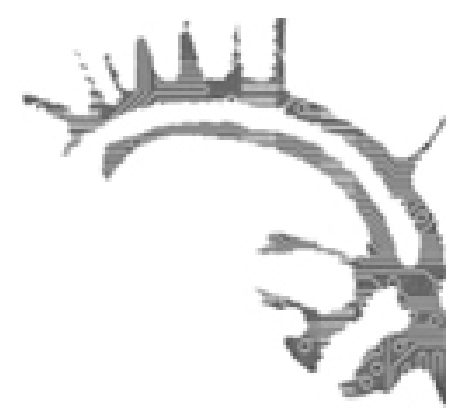

KIRJA-ARVIO

\title{
JOHDATUS SUKUPUOLEEN JA SUKUPUOLENTUTKIMUKSEEN
}

SARESMA, TUIJA \& ROSSI, LEENA-MAIJA \& JUVONEN, TUULA (toim.) 2010: Käsikirja sukupuoleen. Tampere: Vastapaino. 347 sivua.

\section{Anne Häkkinen}

Käsikirja sukupuoleen on syntynyt naistutkimuksen oppiaineen sisällä konkreettisesta tarpeesta: oppialalta on puuttunut alkuvaiheen opiskelijoille tarkoitettu teos, joka valottaa oppialan keskeisiä keskusteluja, käsitteitä ja näkökulmia. Käsillä oleva teos onkin kirjoitettu ensisijaisesti oppikirjaksi sukupuolen- ja naistutkimuksen perus- tai johdantokursseille. Avainsanojen (1996) tapaan kirja esittelee tutkimusalan historialle keskeisiä työvälineitä, mutta tekstien abstraktiotaso on pyritty valitsemaan sellaiseksi, että kirja sopii niille, jotka kohtaavat sukupuolentutkimuksen aiheena ensimmäistä kertaa. Teoksen keskiössä on erityisesti sukupuolen suomalainen tutkimus.

Käsikirja sukupuoleen kytkeytyy myös oppiaineen tarpeeseen määritellä sukupuolentutkimuksen nykytilaa. Teos kuvastaakin Suomessa 2000-luvun ensimmäisen vuosikymmenen lopulla oppialan sisällä käytyjä keskusteluja. Tutkimuksen kohteena olevat asiat ja ilmiöt eivät ole löytäneet yhtä vakiintunutta suomenkielistä vastinesanaa, vaan useampia termejä käytetään rinnakkain, toisinaan yhä kiistellen. Hyvänä esimerkkinä tästä on oppiaineen nimi itsessään. Naistutkimukselle vaihtoehtoisina käsitteinä on käytetty myös feminististä tutkimusta sekä sukupuolentutkimusta. Kirjan kirjoittamisen aikaan keskustelu oppiaineen nimestä on käynnissä, ja sukupuolentutkimus vaikuttaisi vakiintuvan oppiainetta kuvaavaksi kattokäsitteeksi.

Teoksen kirjoittajakaarti koostuu kaiken kaikkiaan 29 humanistisella tai yhteiskuntatieteellisellä alalla toimivasta sukupuolentutkijasta ja yhteiskunnallisesta vaikuttajasta. Sukupuolen rakentumista ja tutkimisen tapoja lähestytäänkin teksteissä humanistisyhteiskuntatieteellisestä näkökulmasta. Teos rakentuu neljästä osiosta, joita esittelen lyhyesti seuraavassa luvussa. Lähempään tarkasteluun olen valinnut joitakin kirjan artikkeleista. 


\section{SUKUPUOLENTUTKIMUKSEN TIETEENTEORIAA, TUTKIMUSKOHTEITA, KÄSITTEITÄ JA TEOREETTISIA KESKUSTELUJA TIIVIISSÄ PAKETISSA}

Teoksen ensimmäisessä osiossa, "Sukupuolen käsityksiä ja käsitteitä”, kartoitetaan sukupuolta, käsitteen käyttötapoja ja sen problematisointia. Osion luvuissa käsitellään sukupuolen suhdetta seksuaalisuuteen, representaatiohin ja valtaan sekä kuvataan sitä, miten sukupuolta on tutkimuksessa hahmotettu kokemuksellisesti ja käsitteellisesti. Esimerkiksi Leena-Maija Rossi tarkastelee omassa artikkelissaan niitä merkityksiä, joita sukupuolelle on länsimaisessa kulttuurissa ja feministisissä keskusteluissa annettu, sekä sitä, miten sukupuoli ja seksuaalisuus on kytketty keskusteluissa toisiinsa. Rossi tuo esille muun muassa sen, että nykyisessä sukupuolentutkimuksessa vallitsee verrattain laaja yhteisymmärrys sukupuolen ja seksuaalisuuden historiallisuudesta. Sukupuoli ja seksuaalisuus, kuten myös niihin liitettävät käsitykset ja arvottamiset, vaihtelevat ajasta ja paikasta riippuen paljonkin, mutta ne myös muuttuvat käsitysten muuttuessa. Sukupuolen lisäksi seksuaalisuuden käsitteestä onkin tullut yksi keskeisistä työkaluista sukupuolentutkijan työkalupakissa. Toinen sukupuolen käsitteellistämiseen liittyvä asia, joka on muuttunut naistutkimuksen oppiaineen olemassaolon aikana, on kysymys sukupuolen ja muiden keskeisten sosiaalisten erojen välisestä suhteesta ja kietoutumisesta yhteen (intersektionaalisuus). Kun aikaisemmin "erolla" tarkoitettiin ennen kaikkea sukupuolieroa, nykyisin ero nähdään myös naisten ja miesten ryhmien sisäisinä eroina. Luokan, sukupuolen ja muiden identiteettikategorioiden, kuten iän tai etnisyyden, yhteisvaikutusten tarkastelu onkin ollut 2000-luvulla sukupuolentutkimuksessa keskiössä. Leena-Maija Rossin sanoin "on siirrytty erosta eroihin".

Teoksen toisessa osassa "Äitiys, mieheys ja queeriys" esitellään sukupuolentutkimuksen painopisteitä. Queer -tutkimus ja transsukupuolisuus ovat problematisoineet sukupuolta uudenlaisella tavalla. Samalla huomion kohteeksi ovat nousseet esimerkiksi vanhemmuuden, mieheyden ja tyttöyden tarkasteleminen kulttuurisina ja ajassa muuttuvina ilmiöinä. Tämän osion luvuista lähempään tarkasteluun nostan Arto Jokisen artikkelin kriittisestä mies- ja maskuliinisuustutkimuksesta. Jokinen lähtee artikkelissaan liikkeelle siitä, miten miestä ja maskuliinisuutta on määritetty mies- ja naistutkimuksen piirissä ja nostaa esille hegemonisen maskuliinisuuden yhtenä keskeisenä käsitteenä kriittisen miestutkimuksen historiassa. Hegemonisella maskuliinisuudella tarkoitetaan tietyssä historiallisessa ajassa ja paikassa esiintyvää kulttuurisesti idealisoitua maskuliinisuutta ja siihen liittyviä hallitsevia arvoja ja maailmankatsomusta. Hegemoninen maskuliinisuus viittaa myös paikkaan sukupuolten välisissä suhteissa, järjestelmään itseensä sekä ideologiaan, joka normalisoi miesten valtaa. Hegemoniseen asemaan pääsee kuitenkin harva miehistä. Suuri enemmistö sen sijaan omaksuu hegemonisen tulkinnan todellisuudesta ja tukee sitä, kun taas muunlaiset maskuliinisuudet alistetaan tai marginalisoidaan. Jokinen kysyykin, onko mielekästä käsitteellistää miehiä sellaisten määreiden avulla, joita he eivät voi todellisessa elämässä saavuttaa.

Kolmannessa osiossa "Sukupuolen kulttuurit ja käytännöt" kohdistetaan huomio kieleen ja siihen, miten sukupuolet merkityksellistyvät ja näyttäytyvät kielessä. Lisäksi 
osion teksteissä osoitetaan, miten sukupuolta kärjistetään ja häivytetään eri elämänaloilla, miten muun muassa mediaa ja teknologiaa tai uskontoa ja tutkimusta voidaan tarkastella läpeensä sukupuolittuneina. Osiossa tarkastellaan myös, miten symbolisen tason sukupuolittavat mekanismit vaikuttavat materiaaliseen elämään sekä ruumiillisiin kokemuksiin. Esimerkiksi Taina Kinnunen pohtii ruumiin sukupuolittamista ja seksualisoimista kosmeettisen kirurgian avulla, kun taas Suvi Keskinen tarkastelee artikkelissaan sukupuolistunutta väkivaltaa ja sen tutkimusta.

Viimeinen kirjan osista, "Neuvotteluja sukupuolesta", liikkuu sekin useilla tasoilla kuvaten moniarvoistumista ja niitä haasteita, joita tasa-arvopuhe tuo mukanaan. Osion luvuissa tavoitteena on esimerkkien kautta osoittaa niitä kohtia, joissa sukupuolikysymyksiin liittyvä aktivismi ja tutkimus ovat edelleen tärkeitä. Esimerkiksi Tuula Juvonen luo artikkelissaan historiallisen katsauksen naisliikkeeseen. Artikkeli pyrkii tekemään näkyväksi ne juuret, joiden varassa muun muassa tasa-arvo on kehittynyt ja kehittänyt yhteiskuntaa. Päivi Naskali puolestaan tarkastelee feministisen kasvatustieteellisen tutkimuksen tehtäviä ja tavoitteita erityisesti suomalaisessa tutkimusperinteessä, ja Maija Urponen kysymyksiä kansalaisuudesta ja kansallisuudesta sukupuolentutkimuksen näkökulmasta.

Kirjan varsinaisten lukujen lisäksi lyhyemmissä, muutaman sivun mittaisissa alaluvuissa luodaan katsauksia suomalaiseen sukupuolen tutkimuksen kenttään tarkastelemalla lähemmin tiettyjä tutkimuksia aina tiettyyn aihealueeseen liittyen. Tällaiset katsaukset ovat toimiva ratkaisu, jonka kautta on ollut mahdollista esitellä konkreettisia tutkimuksia ilman, että varsinaisista luvuista muodostuu lukijan kannalta liian raskaita ja poukkoilevia. Katsausten lisäksi alaluvuissa esitellään muun muassa myös sukupuolten tasa-arvoa ja homo- ja biseksuaaleja sekä transsukupuolisia ihmisiä koskevan lainsäädännön kehittymistä Suomessa.

\section{SUKUPUOLI RUUMIILLISENA, KOKEMUKSELLISENA JA SOSIAALISESTI TUOTETTUNA}

Sukupuolesta ja sen tutkimuksesta rakentuu teoksen artikkelien pohjalta monisyinen kuva. Sukupuoli ei ole pelkkää biologiaa, vaan se on myös kokemuksellinen, ruumiillinen sekä sosiaalisesti ja kulttuurisesti tuotettu. Sukupuoli ei myöskään ole vapaasti valittavissa oleva rooli tai identiteetti, vaan se muotoutuu yhteiskunnallisten ja kulttuuristen käytäntöjen ja normien määräämissä puitteissa.

Nimestään Käsikirja sukupuoleen huolimatta kirjan tarkastelun keskiössä on pääasiassa kuitenkin naissukupuoli. Syitä tähän voidaan etsï sukupuolentutkimuksen tutkimustraditioista, jotka sijoittuvat nais- ja feministiseen tutkimukseen. Naistutkimus on pyrkinyt hyvin yhteiskuntakriittiseen otteeseen, ajamaan tasa-arvokysymyksiä sekä keskustelemaan naisten oikeuksien puolesta, jolloin tutkimuksellinen pääpaino on varsinkin oppialan alkuvaiheessa ollut naissukupuolessa. Kuten oppialan nimikin jo kertoo, naistutkimus perustettiin erityisesti siksi, että naisista haluttiin konkreettista tutkimustietoa erilaisissa yhteyksissä. Kuten Tuula Juvonen, Leena-Maija Rossi ja Tuija Saresma tuovat esille, naistutkimus on alkanut tutkimuksena "naisista, naisille, 
naisina", mutta nykyisin sen piirissä tehty tutkimus ei koske ainoastaan naisia. Naisiin liittyvien kysymysten rinnalle ovat nousseet myös miehiä ja transsukupuolisuutta koskevat kysymykset. Esimerkiksi naiskuvista ja niiden kritiikistä on siirrytty sukupuolittuneiden ja sukupuolittavien merkitysten tutkimukseen. Sukupuolentutkimuksen nimitystä tieteenalalle onkin perusteltu paljon sillä, että sen on ajateltu raivaavan tilaa myös miestutkimukselle. Mies- ja maskuliinisuustutkimus on Suomessa kuitenkin edelleen marginaalista, mikä näkyy myös kirjan sisällössä. Sukupuolen tutkimuksen näkökulmasta käsikirjassa miessukupuoli jää väistämättä naissukupuolen varjoon.

\section{Paikka kirjahyllyssä}

Käsikirja sukupuoleen on tuhti lukupaketti, jossa johdatellaan laaja-alaisesti ja monipuolisesti naistutkimukseen ja feminiiniseen tutkimukseen, käyden läpi oppialan lähtökohtia ja näkökulmia, tieteenhistoriaa, tutkimuskohteita, käytetyimpiä käsitteitä ja teoreettisia keskusteluja. Käsikirjassa ei ole ollut mahdollista mennä kovin syvälle teorioissa ja käsitteissä, eikä se ole ollut teoksen tarkoituksenakaan. Kirja-arvostelua kirjoittaessani olenkin yrittänyt pitää mielessä kohderyhmän, jolle teos on suunnattu eli naistutkimuksen perusopintoja aloittelevat opiskelijat tai ne, jotka tutustuvat sukupuolentutkimuksen maailmaan ensimmäistä kertaa. Miltä teos heidän käsissään saattaisi tuntua ja maistua?

Hyvän oppikirjan kirjoittaminen on haaste, varsinkin jos se pyrkii avaamaan oven aihepiiriin, johon lukija ei aiemmin ole perehtynyt. Vaarana on liian ylimalkainen ja pinnallinen ote siten, että kirjoittajat olettavat lukijan olevan jo hyvin perehtynyt niin käsitteisiin kuin niiden kytköksistä yhteiskunnallisiin, kulttuurisiin ja historiallisiin ilmiöihin. Toisaalta vaarana on sortua myös liian yksityiskohtaiseen informaatioon ja tietotulvaan, jolloin opiskelijat hukkuvat nimiin, vuosilukuihin ja teorioihin, eivätkä kykene tavoittamaan oleellisinta tietoa. Nämä sudenkuopat Käsikirja sukupuoleen onnistuu välttämään kiitettävän hyvin. Artikkeleita on muun muassa kevennetty karsimalla lähdeviitteiden määrää, ja artikkeleiden teemat ovat enemmän aineistoihin ja tutkimuskenttiin kuin kokonaisiin paradigmoihin sitoutuvia. Jos jotakin jäin kaipaamaan, niin historian tutkijoiden näkökulmaa sukupuoleen ja sukupuolentutkimukseen. Joidenkin alalukujen paikkaa ja merkitystä teoksen kokonaisuudessa olisi kenties myös voinut vielä miettiä, mutta pääluvut puolustavat paikkaansa kirjassa. Teos taas puolustaa paikkaansa sukupuolen, vallan ja seksuaalisuuden yhteyksistä kiinnostuneen tutkijan kirjahyllyssä. Varsinkin aihepiiriin tutustuvalle kirja on ehdoton apu, ja sukupuolentutkimukseen jo jonkin verran perehtyneen henkilön käsissä käsikirja toimii hyvänä päivityksenä oppialan keskeisimpiin kysymyksiin. 
Anne Häkkinen: Johdatus sukupuoleen ja sukupuolentutkimukseen

\section{KirJallisuUs}

KOIVUNEN, ANU \& LILJESTRÖM, MARIANNE (toim.) 1996: Avainsanat. 10 askelta feministiseen tutkimukseen. Tampere: Vastapaino.

Filosofian maisteri Anne Häkkinen on etnologian tohtorikoulutettava Jyväskylän yliopiston Historian ja etnologian laitoksella 